\title{
Variants method approach to the preliminary ship design
}

\author{
Podejście wariantowe we wstępnym projektowaniu statków
}

ARTUR KARCZEWSKI
JANUSZ KOZAK *

DOI: https://doi.org/10.17814/mechanik.2017.12.206

\begin{abstract}
Typical ship designing is an iterative method based on the accumulated experience of already built ships. In the case of a completely new type of ship, without the "dowry of previous experience", the design consists in developing a series of parallel variant solutions using the optimization. The paper identifies selected designing methods applying the optimizations used in the preliminary ship design. The optimization methods used in the ship design are discussed.

KEYWORDS: ship design, optimization
\end{abstract}

The ship is an object of large dimensions and technically complicated. The process of its design is a difficult, multi-step task, which is usually solved iteratively. It is often a one-off operation and the prototype is the best (optimal) final product at any given time. It is possible to distinguish many stages of this activity depending on the degree of identification of the designed object, scope and division of the knowledge used and the type of the problem under consideration. The initial stage, on which the main parameters of the ship and the shape of the hull are determined, are referred to as the preliminary design [1-4]. Scientific discipline in the field of shipbuilding, dealing with the methodology of solving such tasks, is the theory of ship design [1]. It includes:

- determination of ship's main dimensions and geometric parameters of hull shape,

- verification calculations in the field of stability and buoyancy,

- development of a preliminary spatial division,

- determination of initial parameters of the drive system,

- shape design of the hull,

- verification calculations based on the developed shape,

- development of a general plan.

There are different definitions of ship design theory. Wiśniewski [5] understands it as a ship design methodology, which is a science about the process of their design (i.e. how to design them, not how they to be designed). According to Michalski [1], this is the knowledge of broadly understood technical and operational properties of ships, dealing with the development of methods for determining the main design parameters of the ship, the shape of the hull and the division of its interior into compartments. In turn, Papanikolaou [2] indicates that it determines - based on

\footnotetext{
*Mgr inż. Artur Karczewski (artkarcz@pg.edu.pl), dr hab. inż. Janusz Kozak (kozak@pg.edu.pl) - Wydział Oceanotechniki i Okrętownictwa Politechniki Gdańskiej
}

project assumptions - the main technical and economic characteristics of the ship through optimization (i.e. by qualitative assessment).

In the case of oversupply in the production of vessels and the rising prices of their construction and operation, the economic aspect in the scale of the whole project translates into the ways of determining individual parameters, characteristics and properties of the ship. Optimal solutions are being sought. In engineering design, a typical example of such an action is to determine the most favorable values of the main structural features of the designed object when its concept is given [6]. In ship designing, this means applying optimization at the initial stage, in the area of determining the parameters of ship's technical solutions [1].

Depending on the number of criteria adopted, one- or multi-criteria optimization is distinguished. However, the application of optimization methods that take into account the simultaneous processing of decision information from many technical fields involved in the design process, is referred to as multidisciplinary or multilevel optimization.

\section{Optimization in shipbuilding}

Optimization uses mathematical methods, therefore the designed object must be defined in terms of mathematics. A simplified mathematical model describes a finite number of design parameters. In the classic approach, the design parameters are the main dimensions of the ship - $L$ (length), $B$ (width), $T$ (draft) and $H$ (lateral height) - and the hull fullness factor $c_{B}$. Their set allows checking the ship's cargo balance.

The purpose functions in ship's initial design in global terms can be divided as follows:

- economic criteria based on the value of invested assets, expenditures incurred and results obtained;

- technical criteria, being derivatives of transport efficiency, based either on the quantities related to the hydrodynamic quality of the hull and the propulsive efficiency, or on mass or volume quantities characterizing the ratios of the load capacity of the unit to its mass or the number of loading units to the volume of the cargo part;

- subjective criteria related to such concepts as ergonomics, aesthetic feelings and useful properties.

\section{Development of ship design methods}

- Primary methods. Initially, building ships was an activity at the border of art and craft. Knowledge has been passed down from generation to generation and 
resulted from tradition and experience. The ships were built "by hand" and "by the eye" of the builder, who was also a designer. The design inspiration came often from observations of nature, where the best solutions were sought. An example may be the eighteenth-century idea of 'cod head and mackerels tail' cod hulls.

The reason for the emergence and development of ship design techniques were wars and the development of trade in the nineteenth century. Fast ships were needed, so they began to think about the hull of better efficiency to navigate faster, and at the same time safe. The development of mathematical representation in the design of the ship is generally attributed to the Swedish officer Fredrick Chapman, who in the search for methods of increasing speed studied solutions used in various types of units. However, neither he nor his contemporaries were able to link the shape parameters of the hull with its resistance properties. Despite the clear need for optimization, it was not able to satisfy it. The search for this relationship has become the main factor in the development of scientific ship design methods in the 20th century.

- Classic method. The classic model of the vessel design process that developed in the 20th century is an iterative process. Its basis is the knowledge acquired on the basis of the population of ships already built, allowing the development and use of statistical-empirical mathematical relationships. The structure of the process requires the execution - in a strictly defined sequence - of a series of consecutive actions, which allows to predict the target of a ship that meets the design assumptions. Most often, such a process is presented in the form of the Evans design spiral.

Based on the assumptions, constraints and design criteria, the main parameters of the ship, such as: length, width, lateral height, draft and engine power, are determined within the scope of acceptable solutions. It is only on the basis of these data that the shape of the hull is determined so that the buoyancy equation is fulfilled. Then, check operations in terms of stability and prediction of drive system parameters are performed. Most often, the optimization elements are limited to activities within one project step. The "temporary" optimization criterion is assumed. Patterns for the optimal parameter are commonly used - for example, according to Posdiunin or the hull fullness factor according to Ayre - or the optimum hull shape is sought to minimize drag (fig. 1). By skillfully using such methods, the designer obtains the best (in his opinion) project [8]. However, if in the next iterative step the solution ceases to be optimal, it is necessary to return to the previous stage and perform subsequent iterations, which increases the costs and extends the design time.

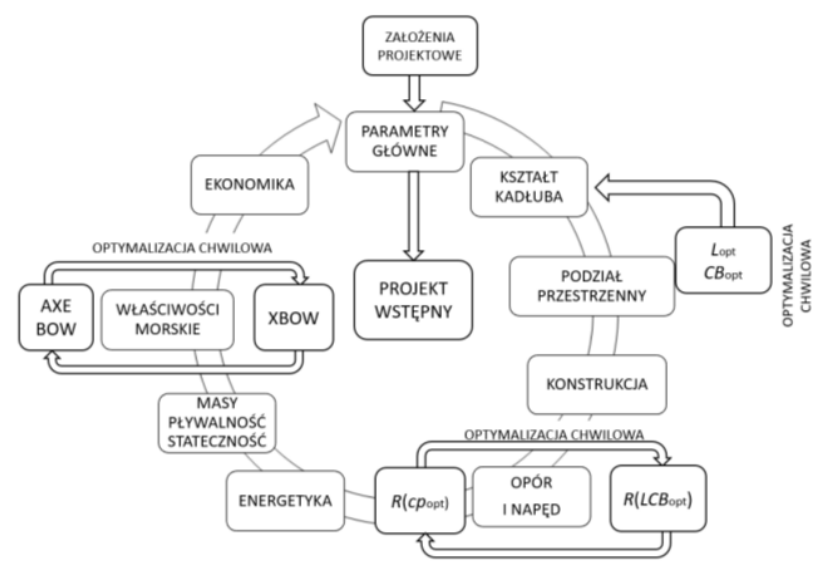

Fig. 1. Design spiral and elements of temporary optimization
- Modern methods. If in the case of a new, unusual ship, analytical description of some properties in the function of main operational characteristics is available and appropriate automatic calculation systems and modeling software are used, then it is possible to perform multivariate, concurrent projects $[9,10]$ allowing optimization [3]. Using digital tools to determine the shape of the hull and its properties (such as hydrostatic data, stability and resistance characteristics), you can consolidate the design process into one optimization algorithm. Thanks to the use of numerical methods, computer graphics and visualization as well as specialized engineering software, the character variants of the ship can be operated already at the initial design stage [5].

- Concurrent design. Chądzyński in his work [10] proposes the use of the reverse process to classical ship design. The selected objective function in the form of a characteristic or economic indicator will determine new variants of the project, while traditional assumptions, such as load capacity or speed of the ship, become results. Then design is a multidisciplinary optimization process. The result is a vector of main dimensions, shape coefficients along with optimal speed and load capacity [7]. This process is called concurrent design (fig. 2). It involves gathering the resources, knowledge and experience of the manufacturer for the purposes of marketing, designing, preparation of production, production and sale of a new product with high quality and low cost. The result is shortening the time needed to design and prepare the production of the product. Examples of the design task solution are presented in [10].

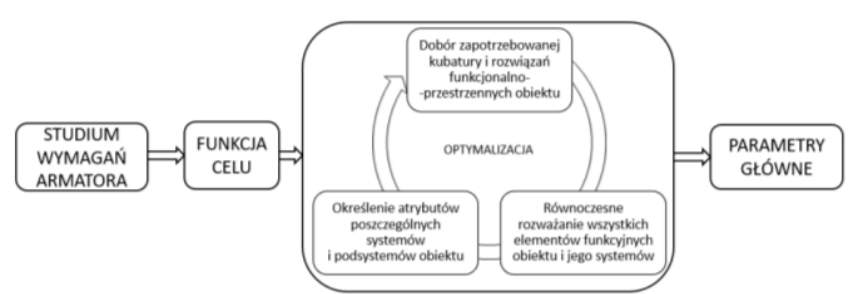

Fig. 2. The scheme of concurrent design based on [10]

- Proposal of a variant approach. In [11, 12], it was proposed to combine automatic and manual design in the form of a multi-variant algorithm to develop the shape of the hull.

The method consisted in the isolation of two design phases (fig. 3). In the first phase, the shape of the hull was adopted as a variable. The fixed parameters were: design assumptions, navigational conditions of the basin and estimated displacement required. The criteria were: allowable angle of heel from people to board in wind conditions, surface area of the damp part of the submarine and minimization of total hull resistance. Types of shapes were manually defined by the designer. In the second phase, the selected hull shape variant was adopted as a constant, while its topology changed. Two programs generating the shape were developed: based on the evolutionary algorithm and on the iterative algorithm. By combining optimization algorithms and decision-making, it was possible to generate a project that fulfills the assumed objective function. 


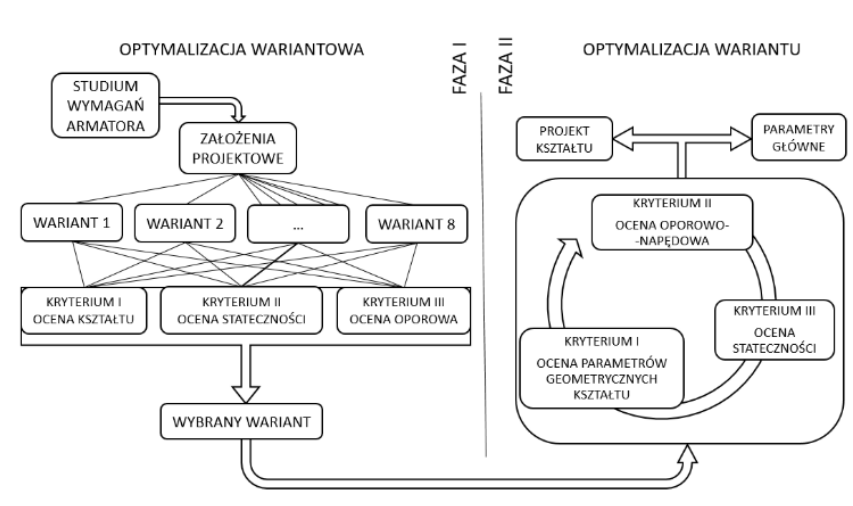

Fig. 3. Variant design scheme

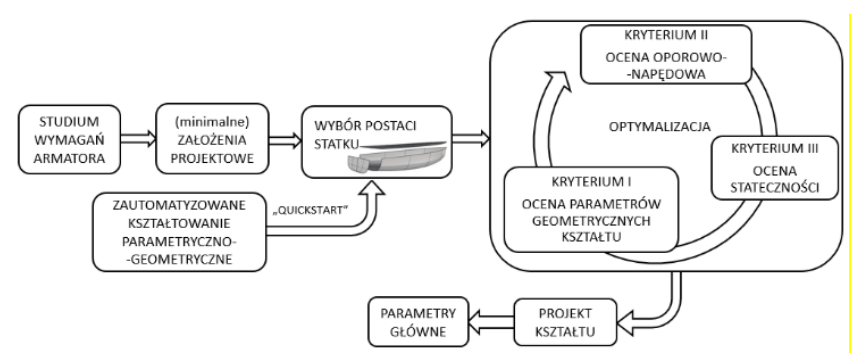

Fig. 4. Form design scheme

- Proposal of a form design method. In his work from 1979, Wiśniewski [5] proposed a method of a form design, in which the parametric model should be reduced to a minimum and treated as a starting point for further geometrical design. Designing begins with the development of a shape (a form, a solid), while the main parameters are the result (fig. 4). Then, the implementation of such an idea was difficult due to the limited computing power of the computers at the time. Currently, this is possible thanks to programs supporting initial design. Due to the quickstart option, which allows you to create a solid in real time by changing its parameters, you can get the initial hull shape design, set by the designer, at the initial stage of work. Then, by building an automated algorithm independent of the designer, the initial form of the hull can be optimized due to selected criteria. In this way, the shape of the hull is obtained with parameters similar to the preset ones, resulting from single- or multi-objective optimization.

\section{Conclusions}

Optimization is not a new concept in shipbuilding. Due to the algorithmization of the design process and the application of optimization methods, the possibilities of formulating a modern ship design methodology open [1]. In turn, automation through the use of computer programs for initial design (eg Rhinoceros 3D + ORCA, MAXSURF, AVEVE Marine, NAPA) significantly speeds up calculations. Often, however, the calculation is carried out iteratively, and the system operator decides on concurrency and variability [7]. The process still largely depends on the designer's knowledge. The classic method remains unchanged, while tools change. The application of optimization in the initial design allows to combine the phases of parametric calculations and the development of the hull shape into one stage. Multivariate optimization enables the development of an efficient method for the initial design of a ship that does not require a constant reference to the ships already built and to the empirical and statistical relationships. In the post-military perspective, this means reducing work and time expenditure throughout the ship's design process.

\section{REFERENCES}

1. Michalski J. „Podstawy teorii projektowania okrętów”. Gdańsk: Wydawnictwo Politechniki Gdańskiej, 2013.

2. Papanikolaou A. "Ship Design, Methodologies of Preliminary Design". London: Springer, 2014.

3. Piskorz-Nałęcki J.W. „Projektowanie statków morskich”. Szczecin: Wydawnictwo Uczelniane Politechniki Szczecińskiej, 1981.

4. Nogid L. „Teoria projektowania okrętów”. Gdynia: Wydawnictwo Morskie, 1962.

5.Wiśniewski J. „Projektowanie postaciowe w metodyce projektowania okrętów". Gdańsk: Politechnika Gdańska, 1979.

6. Tarnowski W. „Podstawy projektowania technicznego". Warszawa: Wydawnictwa Naukowo-Techniczne, 1997.

7. Abramowski T. „Elementy multidyscyplinarnej optymalizacji wskaźników techniczno-ekonomicznych we wstępnym projektowaniu współbieżnym statków transportowych". Szczecin: Wydawnictwo Uczelniane Zachodniopomorskiego Uniwersytetu Technologicznego w Szczecinie, 2011.

8. Oleksiewicz B. „Morfologia metodyki projektowania okrętów. Dobór głównych parametrów statku". Gdańsk: Politechnika Gdańska, Instytut Okrętowy, 1976.

9. Sekulski Z. „Wybrane problemy optymalizacji wilokryterialnej we wstępnym projektowaniu konstrukcji kadłuba statków morskich". Szczecin: Wydawnictwo Uczelniane Zachodniopomorskiego Uniwersytetu Technologicznego w Szczecinie, 2012.

10. Chądzyński W. „Elementy współczesnej metodyki projektowania wybranych obiektów”. Szczecin: Wydawnictwa Naukowe Politechniki Szczecińskiej, 2001.

11. Karczewski A., Piątek $Ł$. "Reducing the Environmental Impact of the Public Water Transportation Systems by Parametric Design and Optimization of Vessels' Hulls. Study of the Gdańsk's Electric Passenger Ferry (2015-2016)". W: Architecture for the Society of Knowledge. Warszawa, 2016.

12. Karczewski A., Kozak J. "Variant designing in the preliminary small ship design process". Polish Maritime Research. 94, 2 (2017): pages 77-82. 